\title{
27. Language exposure by outside-of-class communication activity in English departments
}

\author{
Sevdenur KÜÇÜKLER ${ }^{1}$ \\ Sofia SULAC ${ }^{2}$ \\ Halil KÜÇÜKLER ${ }^{3}$
}

APA: Küçükler, S.; Sulac, S.; Küçükler H. (2021) Language exposure by outside-of-class communication activity in English departments. RumeliDE Dil ve Edebiyat Araştırmaları Dergisi, (Ö9), 336-344. DOI: 10.29000/rumelide.984793.

\begin{abstract}
Outside-of-class communication activities are connected with giving learners a positive impact on outdoor activites, positive impact on physical activities, increased emonional variability. This, in turn, influences learning, mood, and behavioral benefits making learners more willing to learn foreign languages, which further guarantees progress. The main question under discussion in Gagauzian and Turkish educational institutions is to what extent and how language learning ought to be monitored. The purpose of the study is that exposure of language to students who study foreign languages in Komrat University of Gagauzia and students who study in English department at Balıkesir University is discussed. The study was carried out during 2020 academic year. There were 102 participants from Balıkesir University and 108 participants from Komrat University. The research instrument was outdoor activities survey questions to reveal the impact of language exposure in the university and outside of the university, as well. Research questions were directed to students to measure how much of their time outside of school were exposed to English. The participants were asked to choose the frequency at which they used some language exposure items. In the Questionnaire, the students from Komrat and Balikesir educational institutions were examined on the level of exposure to the English language daily. Similarly, it was evident from the responses that there were massive differences between the language exposures of participants in Komrat and Balikesir universities, which reveals that those from Balikesir in Turkey were more exposed to the English language compared to those students from Komrat university in Moldavia.
\end{abstract}

Keywords: Outdoor techniques, foreign language learning, out-of-school learning

\section{İngilizce bölümlerinde okul dışında dile maruz kalma}

\section{$\ddot{0} \mathbf{z}$}

Okul dışı aktiviteler, öğrencilere okul dışı öğrenme üzerinde, fiziksel etkinlikler üzerinde olumlu etki, artan duygusal değişkenlik sağlamakla bağlantılıdır. Bu da öğrenmeyi, ruh halini ve davranışsal faydaları etkiler, öğrencilerin yabancı dil öğrenmeye daha istekli olmasını sağlar ve bunun sonucu olarak ilerlemeyi daha da verimli hale getirir. Gagauz ve Türk eğitim kurumlarında tartışılan ana gündem, dil

Doktora, Komrat Devlet Üniversitesi, Yabancı Diller, (Komrat, Moldova), nurkucukler@gmail.com, ORCID ID: 0000-00018769-0662, [Araștırma makalesi, Makale kayıt tarihi: 26.07.2021-kabul tarihi: 20.08.2021; DOI: 10.29000/rumelide.984793] Dr., Komrat Devlet Üniversitesi, Yabancı Diller, (Komrat, Moldova), sulak_sofia@mail.ru, ORCID ID: 0000-0003-2325-548X Dr. Öğr. Gör., Balıkesir Üniversitesi, Yabancı Diller Yüksekokulu, (Balıkesir, Türkiye), hkucukler2@gmail.com, ORCID ID: 00000002-7674-540X

RumeliDE Dil ve Edebiyat Araşturmaları Dergisi Osmanağa Mahallesi, Mürver Çiçeği Sokak, No:14/8 Kadıköy - ISTANBUL / TÜRKIYE 34714 e-posta: editor@rumelide.com tel: +90 $5057958124,+902167730616$
Address

RumeliDE Journal of Language and Literature Studies Osmanağa Mahallesi, Mürver Çiçeği Sokak, No:14/8

Kadıköy - ISTANBUL / TURKEY 34714

e-mail: editor@rumelide.com

phone: +90 505 7958124, +90 2167730616 
öğreniminin ne ölçüde ve nasıl izleneceğidir. Çalışmanın amacı, Gagavuzya Komrat Üniversitesi'nde yabancı dil okuyan öğrenciler ile Balıkesir Üniversitesi İngilizce bölümünde okuyan öğrencilerin okul dışında dil öğrenme aktivitelerinin dil öğrenmelerini ne ölçüde etkilediğidir. Çalışma 2020 akademik yılında gerçekleştirildi. Balıkesir Üniversitesi'nden 102, Komrat Üniversitesi'nden 108 katılımcı vardı. Araştırma aracı, üniversite dışında dile maruz kalmanın etkisini ortaya çıkarmak için okul dışı aktivite anket sorularıydı. Araștırma soruları, okul dışındaki zamanlarının ne kadarının İngilizceye maruz kaldığını ölçmek için öğrencilere yönlendirildi. Katılımcılardan bazı dile maruz kalma maddelerini, kullandıkları sıklı̆̆ı seçmeleri istendi. Ankette, Komrat ve Balıkesir eğitim kurumlarından gelen öğrenciler, günlük İngilizceye maruz kalma düzeyleri açısından incelenmiştir. Benzer şekilde, Komrat ve Balıkesir üniversitelerindeki katılımcıların dil maruziyetleri arasında büyük farklılıklar olduğu ortaya çıktı, bu da Türkiye'deki Balıkesirli'deki öğrencilerin Moldova'daki Komrat üniversitesindeki öğrencilere göre İngilizceye daha fazla maruz kaldıklarını ortaya koydu.

Anahtar kelimeler: Sınıf dışı öğrenme teknikleri, yabancı dil öğrenimi, okul dışı öğrenme

\section{Introduction}

In all of the school arenas, there has been a growing concern for students to speak foreign languages, especially English. Therefore, the lack of practicing of a language hampers their speaking in a foreign language and hence create the need to solve this problem. Students that can not be speak a foreign language fluently, especially English find themselves unable to communicate clearly during speaking. This can be frustrating and hence helping to solve failure in speaking a foreign language. For this reason, this research advocates that if scholars can embrace speaking in English during university eduction. This research was carried out to determine the exposure of students studying in universities to English, especially in learning a foreign language and was conducted on the English exposure of students studying in Balıkesir University, Necatibey Faculty of Education, Department of English Language Teaching and Komrat University, Faculty of National Culture, English Department.

This research was carried out to determine the exposure of students studying in universities to English, especially in learning a foreign language and was conducted on the English exposure of students studying in Balıkesir University, Necatibey Faculty of Education, Department of English Language Teaching and Komrat University, Faculty of National Culture, English Department.

Language is a systematic means of communicating by the use of sounds or conventional symbols.The cognitive processes involved in producing and understanding in producing and undersatnding linguistic communication. Exposure to language motivate students' willingness to learn. By modeling and encouraging a safe environment and purposeful rules, students feel motivated to do the right thing and help one another. It is important for teachers to put an emphasis on intrinsic motivation in the classroom to keep students interested and invested in their own learning goals. With this study, it is going to be revealed how students are exposed to language at school and outside the school and how this affects their success in learning a language and contributes to students to learn languages by guiding outside the school.

\section{The importance of outside-of-class communication activity (OCC)}

Research provides that the impact of the outside of class communication practices between instructors and learners in literature have been debated upon for a prolonged period. Research further reveals that learners

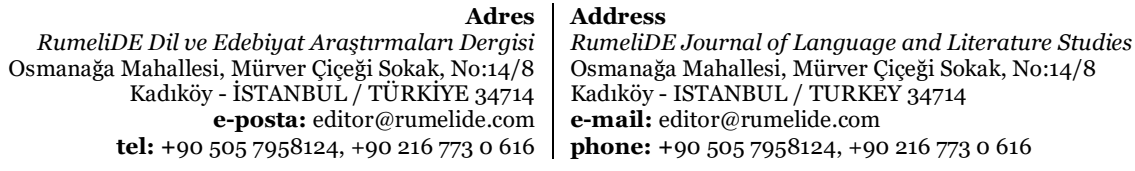



344)

engaging in such outside of class interactions with their ELL's instructors have enhanced academic performances due to the increased trust and motivational levels in their instructors compared to others (Nadler \& Nadler, 2000). This is because such activities are linked with the instructors, non-verbal and verbal immediacy, learners' motivation, and trust, which further guarantees success. This is further supported by Nadler \& Nadler (2000), in his argument that increased levels of outside of class communication are positively linked with enhanced retention, academic performance, and learner satisfaction.

Pascarella and Terenzini (1991) suggest that both informal and formal communication with learners in and outside classrooms enhances the relationship between faculties and learners. This further enables learners to seek help and share their problems and other issues with their faculties' staff, making them feel increasingly motivated and valued. Currently conducted research further proves the existence of a positive relationship between out of class communication (faculty and students) and learner's retention levels. This, therefore, raises the need for understanding and acknowledging out-of-class communication and its impact on faculties, learners, and higher educational institutions (d'Ydewalle \& De Bruycker, 2007). In this case, OCC helps students expand their knowledge on their educational courses, increasing their confidence, motivating them to acquire higher academic qualifications, which further helps in achieving higher academic grades. From the research, learners involved with OCC cherished their academic experiences and enjoyed staying in their educational institutes, which further made them more willing to join ELL's sessions. Instructors involved in OCC also had increased evaluations compared to those others.

Even though OCC has many benefits, research shows that most educational institutions do not incorporate such practices. In this case, most instructors believe that their duties are only class teaching, which should not be the case (Cotton \& Wilson, 2006). Approximately 23 percent of learners from the survey revealed that they had not interacted with their instructors outside classroom sessions, which further reveals a lack of informal teaching. Similarly, 50 percent of learners revealed having fewer interactions with their instructors after class sessions, and their informal meeting lengths were shorter. Most OCC sessions also discuss course works. This shows that more should be done to ensure the student's active interactions with their teachers. This is based on the fact that when students feel taken care of and valued by their instructors, they become loyal to their institute, which has a positive impact on their performances (Aylor \& Oppliger, 2003).

In this case, instructors' attitudes influence OCC interactions, which means that when teachers use welcoming, helping, and polite attitudes, learners would be more willing to join OCC activities compared to those exposed to instructors with unwelcome and rude gestures, whether nonverbal or verbal (Nadler \& Nadler,2000). Since verbal immediacy is directly linked with learner's satisfaction and motivation of OCC activities, it is right to say that instructor's immediacy improves the learner's motivation in learning. Furthermore, learners develop individualized trust with the instructors whom they engage with in OCC activities, which further proves the positive relationship between individualized trust and instructors' behaviors (Spada, 2006). When learners have increased trust in their instructors, they tend to engage in OCC more.

\section{Methodology}

\section{Research design}

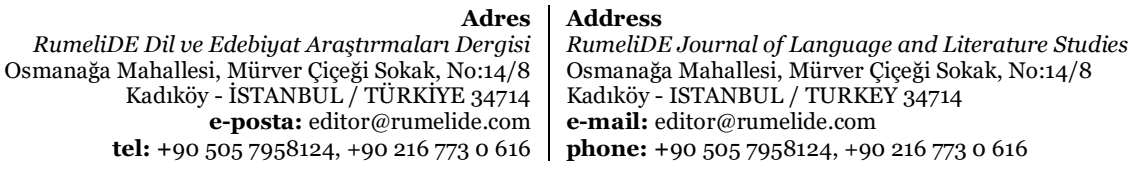


This part indicates the research methodology. This part divided into three parts as research design, participants, instruments, data analysis. The present study embraced a comparative approach to research, gather data and analyse it. The data that was collected regards the influence of language exposure learning on university student's speaking level in English learning. Experimental research design involves the manipulation of a variable of interest while randomizing the dependent factors. The comparative research design included two different 'study group' of respondents whose results were compared with that of another group. Another part of the study involved a survey. The comparative research design was quantitative in nature, as opposed to qualitative. Quantitative research was ideal for the present study because it allows the researcher to analyse data using statistical manipulation, as opposed to analysis based on story narrations as in the case of the qualitative approach. Quantitative research facilitated quantification of the degree to which the university students can speak in their foreign language development.

The current comparative and quantative study adopted as descriptive research design. This research design basically refers a research designed to describe the target population. It involves collection of quantitative information that can tabulated along a continuum in numerical form and it means collecting data that describes the issue under investigation and then organizes, tabulates, and describes the issue. The study was conducted at the English departments at Balıkesir University in Turkey and at Komrat University in Gagauzia/Moldova in the academic year 2020 to investigate the impact of language exposure in the university and outside of the university, as well. Marking the answer options of the research questions used in this study was based on volunteering.

\section{Participants}

The research used purposive sampling to recruit participants. Purposive sampling was convenient for the researcher because it saves time. This characteristic of purposive sampling is accrued to the fact that, in this sampling strategy, the researcher had the freedom to recruit participants purposively as long as they were willing to take part in the study two groups for the research.

The study was carried out during 2020 academic year for students in the English Departments at the Faculty of Necatibey at Balıkesir University and Komrat University. There were 102 participants from Balıkesir University and 108 participants from Komrat University. The participants were randomly selected and based on volunteerism to participate in this study. The target population consisted of male and female university students.

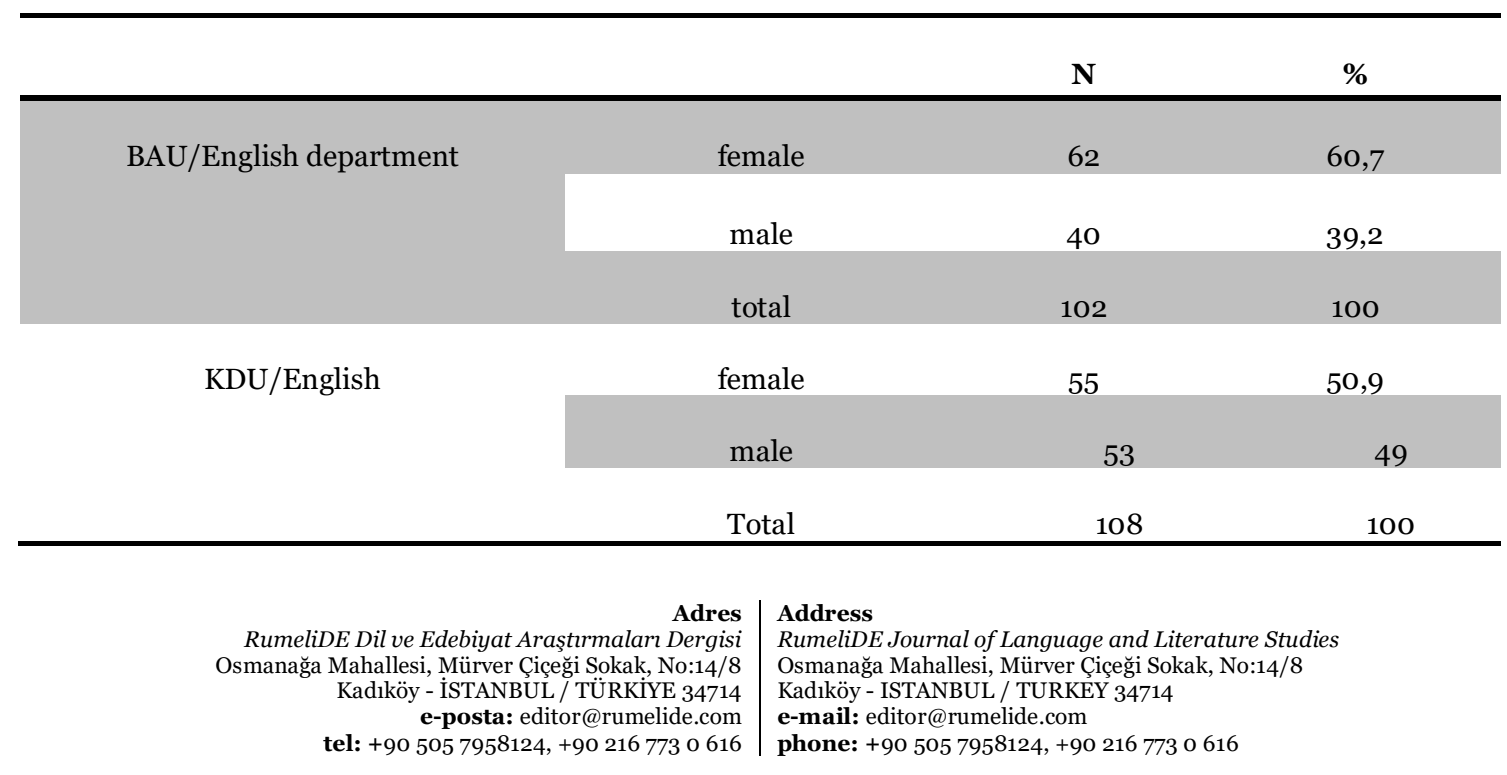


Table 1: Demographic Information of the Participants

\section{Instruments}

The research instrument was outdoor activities survey questions to reveal the impact of language exposure in the university and outside of the university, as well. Research questions were directed to students to measure how much of their time outside of school were exposed to English. The participants were administered with questionnaires in which they identified on language exposure. The participants were asked to choose the frequency at which they used some language exposure items.

\section{Data analysis}

To analyze the results that were collected from the data of the questionnaires were analysed according to the classification of averages method stated under the subtitles of language exposure, language exposure at home, language exposure among friends, language exposure at school, exposure from media.

\begin{tabular}{lll}
\hline Frequency & Description & Score \\
\hline High & Always or almost always & 4.5 to 5.00 \\
& Generally used & 3.5 to 4.4 \\
\multirow{2}{*}{ Medium } & Sometimes & 2.5 to 3.4 \\
& Generally not used & 1.5 to 2.4 \\
Low & Almost or almost never used & to 2.4 \\
\hline
\end{tabular}

Table 2: The Classification of Language Exposure

Table 1 shows that data collected was then analysed quantitatively using the SPSS software. Ethical considerations regarding the process of data collection and use were taken into account during the study (Iamudom \& Tangkiengsirisin, 2020).

\section{The results of the study}

In the Questionnaire, the students from Komrat and Balikesir educational institutions were examined on the level of exposure to the English language daily. The table below reveals the findings of the questionnaire. Similarly, it was evident from the responses that there were massive differences between the language exposures of participants in Komrat and Balikesir universities, which reveals that those from Balikesir in Turkey were more exposed to the English language compared to those students from Komrat university in Moldavia (Al Zoubi, 2018). For instance, there was increased rates of Balikesir's students interaction with people addressing them in english $(6,45)$ than those in Komrat university $(2,78)$. This is based on the fact that the more individuals interact with others in English, the more they acquire knowledge of the language, which further makes it easier to communicate not only in school settings but also in their daily lives (Alaga \& Palencia, 2015). Again, this is important due to the increased need to use English as a universal language currently. The same is also true with regard to research conducted by Lindgren and Munoz (2013) in various educational institutions located in Europe. The discussed studies of the above reputable researchers on language exposure reveal that even though contextual language learning is implemented in out of school communication activities, much needs to be done to inquire on the impact of English as a second language in students.

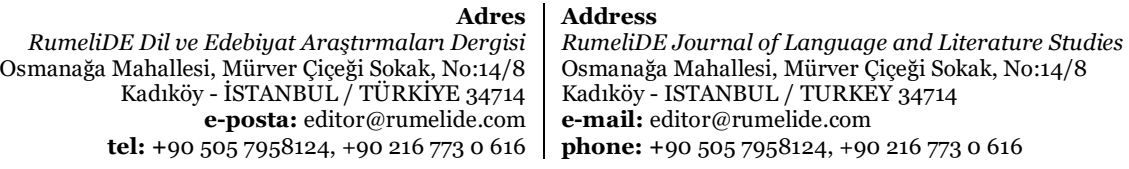


Various contexts in which the students used the English language strongly reveal the dissimilarities in the amount of English exposure, which is further explained in the table below. From the results, it is evident that an increase in the levels and rates of English exposure strengthens the English language.

\begin{tabular}{|c|c|c|c|}
\hline Values & Moldavia & Turkey & $\begin{array}{l}\text { Grand } \\
\text { Total }\end{array}$ \\
\hline 1. How many hours that you had people speaking English directly to you? & 2,78 & 6,45 & 4,80 \\
\hline $\begin{array}{l}\text { 2. How many hours that you had people speaking English around you (not } \\
\text { directly involving you in the conversation)? }\end{array}$ & 3,39 & 2,41 & 2,85 \\
\hline 3. How many hours did you spend watching English movies with subtitles? & 4,17 & 5,09 & 4,68 \\
\hline 4. How many hours did you spend on watching English movies without subtitles? & 3,50 & 2,73 & 3,08 \\
\hline 5. How many hours did you spend on listening to English songs? & 6,53 & 4,05 & 5,16 \\
\hline $\begin{array}{l}\text { 6. How many hours did you spend on watching TV series and/or cartoons in } \\
\text { English? }\end{array}$ & 3,44 & 5,32 & 4,48 \\
\hline 7. How many hours did you spend on talking to people face-to-face in English? & 1,11 & 2,11 & 1,66 \\
\hline 8. How many hours did you spend on talking on the phone in English? & 1,28 & 1,36 & 1,33 \\
\hline $\begin{array}{l}\text { 9. How many hours did you spend on online writing (texting, writing E-mails, } \\
\text { writing a blog, etc.)? }\end{array}$ & 2,03 & 1,61 & 1,80 \\
\hline $\begin{array}{l}\text { 10. How many hours did you spend on writing in English by hand (except doing } \\
\text { your homework)? }\end{array}$ & 1,25 & 3,48 & 2,48 \\
\hline $\begin{array}{l}\text { 11. How many hours did you do online reading in English (readings that are not } \\
\text { relevant to your schoolwork)? }\end{array}$ & 3,33 & 2,55 & 2,90 \\
\hline $\begin{array}{l}\text { 12. How many hours did you spend on reading magazines/books/newspapers } \\
\text { (not online)? }\end{array}$ & 2,06 & 1,41 & 1,70 \\
\hline $\begin{array}{l}\text { 13. How many hours did you spend on watching video clips in English on } \\
\text { the internet? }\end{array}$ & 3,83 & 3,64 & 3,73 \\
\hline
\end{tabular}

Table 3: The English language exposure of students in Komrat and Balikesir Universities.

Generally, from the table 3, it is evident that approximately 97 percent of students from Komrat and Balikesir universities listened to music daily (d'Ydewalle \& De Bruycker, 2007). However, the rate of listening to music was more in Moldavia students $(6,53)$ than those in Turkey $(4,05)$. Such activities are however not surprising since most students provided that most radio stations present their songs in the English language, which means that even individuals not intentionally looking for chances to listen to music in English can hear such songs when they tune in to most radio platforms, especially those aimed at youth or younger audiences. Similarly, from the participant's responses in the questionnaires, it was evident that the most minimal activities were watching movies with no subtitles which was represented by 3,50 in Moldavia students and 2,73 in Turkey students. This means that more than half of the students watched movies with subtitles, which is, 5,09 for Turkey University (Balikesir) and 4,17 for Moldavia University (Komrat).

Even though listening to music in English was linked with much lower proficiencies in language than other language exposures, research provides that, to some extent, English music contributed to enhanced writing and reading comprehension and also contributed to knowledge on receptive vocabularies (Palencia, 2009). Generally, the impact of language exposure cannot be ignored since it accounted for 23 percent speaking variance, 16 percent of writing and reading comprehension variance, 17 percent of enhanced listening

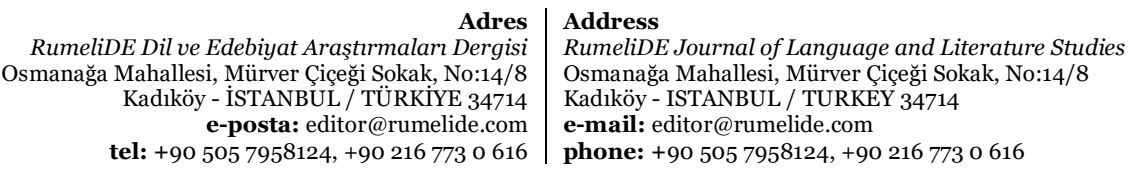


comprehension, and 18 percent of receptive vocabulary transformation in students, which not only guarantees academic progress but also enhanced interactions in the real-life world (Al Zoubi, 2018). This further means that overall exposure accounted for 22 percent of students' total language proficiencies from both universities.

From the responses, activities involving reading books and novels were minimal. For instance, of the 16 percent of students who regularly read books, only 5 percent read English novels, magazines, or comics (Alaga \& Palencia, 2015). In this case, students in Komrat university spent more hours reading online articles not necessarily linked to course work $(3,33)$ compared to those in Balikesir university $(2,55)$. The results were also the same for hours spent reading newspapers, books, and magazines whereby Moldavia students outdid Turkey University (2,06 and 1,41 respectively). Most of the students who reported reading English books said they did so for 30 minutes or less, while only a few revealed reading English books for over two hours every day (Alaga \& Palencia, 2015). Generally, the information shows that students from both Komrat and Balikesir were exposed to the English language daily, although in distinct media forms. From the research, reading English books was done for pleasure and study purposes rather than reading them in their native tongues (Dofradoiter et al., 2010).

With regard to watching videos and films on television, students from Turkey revealed having increased exposure to English television programs $(5,32)$ compared to those from Moldavia $(3,44)$. Generally, roughly 80 percent of the students from both schools depicted that they watched such films with subtitles in their home tongue, this represents 4,17 in Moldavia and roughly 5,09 among Turkey students. 78 percent revealed internet surfing and using media platforms in English on a daily basis, in this case, Moldavia $(2,03)$ depicted increased incorporation of English in online writing compared to Balikesir students in Turkey $(1,61)$. Also, from the study, the most popular media platforms are YouTube, Facebook, Radio, Snapchat, Instagram, broadcasting and creating videos. The most commonly used games were FIFA and Minecraft. The findings are in agreement with Koolstra and Beentjes (1999) studies that are based on the argument that subtitled movies, music, and short films contributed to expanding an individual's vocabulary on foreign languages.

Accordingly, exposure to English language with regard to watching television films was also significantly higher in Balikesir students $(5,32)$ than Komrat students $(3,44)$. The study is also in line with studies conducted by Peters and Webb (2018), which involved exposing adults to full-length television films. The results showed that contextual learning developed in which the participants showed enhanced vocabularies (Webb, 2010). This means that students can learn newer vocabularies of particular foreign languages through exposure to watching TV in the target language regardless of the presence of native language subtitles.

\section{Conclusion}

Research provides that there is an association between speaking English and using media platforms as dependent variables. The most method of outside of school language exposure was by listening to English music. From the study, it was evident that approximately 97 percent of students from Komrat and Balikesir universities listened to music daily. However, the rate of listening to music was more in Moldavia students $(6,53)$ than those in Turkey $(4,05)$. Also, most students revealed that gaming and watching films with subtitles proved useful in expanding their speaking skills and receptive vocabularies which not only improves their performances but also enhances their interaction in the increasingly globalized world. In this case, more than half of the students watched movies with subtitles, which is, 5,09 for Turkey University

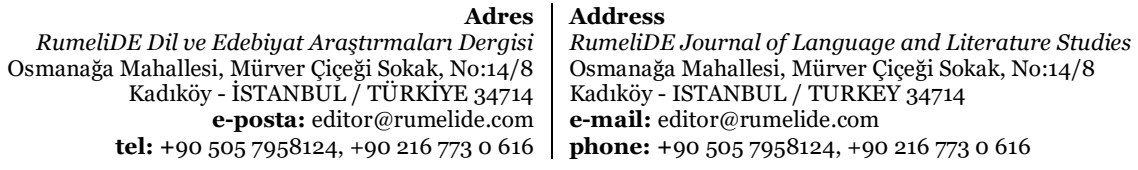


(Balikesir) and 4,17 for Moldavia University (Komrat). 78 percent also revealed internet surfing and using media platforms in English on a daily basis, in this case, Moldavia $(2,03)$ depicted increased incorporation of English in online writing compared to Balikesir students in Turkey $(1,61)$. This is further supported by Nadler \& Nadler (2000), in his argument that increased levels of outside of class communication are positively linked with enhanced retention, academic performance, and learner satisfaction. Further research however should be conducted to expand the knowledge on the association between outside communication activities and language acquisition.

The study mainly focused on the association between, the student's vocabulary knowledge, gender, instruction levels, and amount of outside of school exposures (Balikesir and Komrat universities). Unlike students in Komrat, Balikesir students were more exposed to the English language outside classroom environments, increasing their English language strength, vocabulary scores, and increased informal learning opportunities. Digital technology also played a significant role in language exposure, through interaction with people speaking in English, internet surfing, and gaming. Most importantly, the results show that outside of school language exposure is essential for increasing vocabulary size, it acts as a supplement for the formal settings and instructions provided in schools therefore exposing the students more, which further guarantees improved literature scores and their interactions in the real world settings.

\section{References}

Alaga, N. A. C., \& Palencia, R. S. (2015). Media Exposure and Students' Communicative English as Second Language (ESL) Performance. Countryside Development Research Journal, 3(02), p. 71-81.

Al Zoubi, S. M. (2018). The impact of exposure to English language on language acquisition. Journal of Applied Linguistics and Language Research, 5(4), p. 151-162.

Aylor, B., \&Oppliger, P. (2003). Out of class communication and student perceptions of instructor humor orientation and socio-communicattive style. Communication Education, 52(2), p. 122-134.

Cotten, S. R., \& Wilson, B. (2006). Student-faculty interactions: Dynamics and determinants. Higher Education, 51, p. 487-519.

d'Ydewalle, G., \& De Bruycker, W. (2007). Eye movements of children and adults while reading television subtitles. European psychologist, 12(3), p. 196-205.

Iamudom, T., \&Tangkiengsirisin, S. (2020). A Comparison Study of Learner Autonomy and Language

Learning Strategies among Thai EFL Learners. International Journal of Instruction, 13(2).

Lindgren, E., \& Muñoz, C. K. (2013). The influence of exposure, parents, and linguistic distance on young European learners' foreign language comprehension. International Journal of Multilingualism, 10(1), p.105-129.

Nadler, M. K., \& Nadler, L. B. (2000). Out of class communication between faculty and students: A faculty perspective. Communication Studies, 51(2), 176-188. Retrieved from: https://www.tandfonline.com/doi/abs/10.1080/10510970009388517

Palencia, R. S. (2009). Correlates of the Oral English Performance in the Seven Language Functions of the First Year Nursing Students of Samar State University: Inputs for Improved English Instructional Program. Unpublished Master's Thesis, Samar State University, Catbalogan City.

Pascarella and Terenzini (1991). How College Affects Students: Twenty years of research on college students: Lessons for future research, 83-92.

Peters, E., \& Webb, S. (2018). Incidental vocabulary acquisition through viewing L2 television and factors that affect learning. Studies in Second Language Acquisition, 40(3), p.551-577.

Spada, N. (2006). How Languages Are Learned. Oxford: Oxford University.

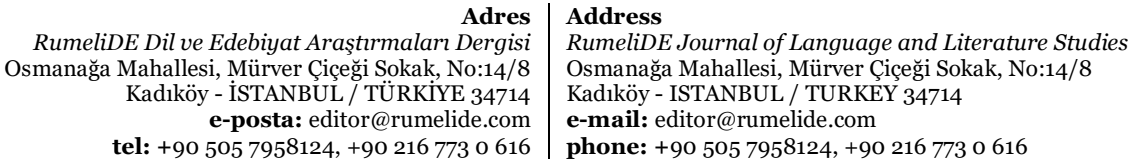


344 / RumeliDE Journal of Language and Literature Studies 2021.S9 (August)

Language exposure by outside-of-class communication activity in English departments / S. Küçükler; S. Sulac; H. Küçükler (pp. 336344)

Webb, S. A. (2010). Corpus driven study of the potential for vocabulary learning through watching movies. International Journal of Corpus Linguistics, 15(4), p. 497-519.

Adres | Address

RumeliDE Dil ve Edebiyat Araşttrmaları Dergisi $\quad$ RumeliDE Journal of Language and Literature Studies Osmanağa Mahallesi, Mürver Çiçeği Sokak, No:14/8 Osmanağa Mahallesi, Mürver Çiçeği Sokak, No:14/8

Kadıköy - İSTANBUL / TÜRKIYY 34714 Kadıköy - ISTANBUL / TURKEY 34714

e-posta: editor@rumelide.com e-mail: editor@rumelide.com

tel: +90 505 7958124, +90 216773 o 616 phone: +90 505 7958124, +90 2167730616 